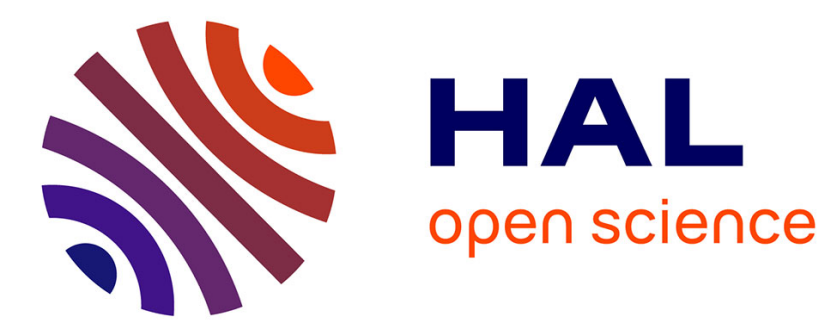

\title{
A new approach for tracking seed dispersal of large plants: soaking seeds with $15 \mathrm{~N}$-urea
}

Xianfeng Yi, Guoqiang Liu, Mingming Zhang, Zhong Dong, Yueqin Yang

\section{To cite this version:}

Xianfeng Yi, Guoqiang Liu, Mingming Zhang, Zhong Dong, Yueqin Yang. A new approach for tracking seed dispersal of large plants: soaking seeds with 15 N-urea. Annals of Forest Science, 2014, 71 (1), pp.43-49. 10.1007/s13595-013-0331-7 . hal-01098382

\section{HAL Id: hal-01098382 \\ https://hal.science/hal-01098382}

Submitted on 24 Dec 2014

HAL is a multi-disciplinary open access archive for the deposit and dissemination of scientific research documents, whether they are published or not. The documents may come from teaching and research institutions in France or abroad, or from public or private research centers.
L'archive ouverte pluridisciplinaire HAL, est destinée au dépôt et à la diffusion de documents scientifiques de niveau recherche, publiés ou non, émanant des établissements d'enseignement et de recherche français ou étrangers, des laboratoires publics ou privés. 


\title{
A new approach for tracking seed dispersal of large plants: soaking seeds with ${ }^{15} \mathrm{~N}$-urea
}

\author{
Xianfeng Yi • Guoqiang Liu • Mingming Zhang • \\ Zhong Dong • Yueqin Yang
}

Received: 20 December 2012 / Accepted: 10 September 2013/Published online: 25 September 2013

(C) INRA and Springer-Verlag France 2013

\begin{abstract}
- Context Although various tracking methods have been used in many ecosystems to investigate seed dispersal and seedling recruitment, it is still difficult to measure seed dispersal patterns due to methodological challenges in tracking seed movement away from parent trees and in finding the locations of seedlings.

- Aim Here, we aimed to develop a new approach to track seed dispersal by animals in the field.

- Methods Our approach involves soaking seeds directly into

${ }^{15} \mathrm{~N}$-urea solutions with different dosages to enrich them isotopically. This new method is expected to create a reliable differentiation between the enriched seeds and natural ones and consequently between the corresponding seedlings.

- Results We showed that acorns of Quercus variabilis and Cyclobalanopsis glauca and seeds of Pinus koraiensis soaked in ${ }^{15} \mathrm{~N}$-urea solutions were successfully enriched. We did not find that $\delta^{15} \mathrm{~N}$ value of seeds was a linear function of ${ }^{15} \mathrm{~N}$-urea soaking duration. However, with high urea dosage and extending soaking duration, the $\delta^{15} \mathrm{~N}$ values in seedlings of
\end{abstract}

Handling Editor: Michael Tausz

Contribution of the co-authors Conceived and designed the experiments: Xianfeng Yi. Performed the experiments: Guoqiang Liu, Mingming Zhang, and Zhong Dong. Analyzed the data: Xianfeng Yi and Yueqin Yang. Wrote the paper: Xianfeng Yi. Guoqiang Liu and Mingming Zhang contributed equally to this work.

X. Yi $(\bowtie)$

College of Life Sciences, Jiangxi Normal University,

Nanchang 330022, China

e-mail: yxfeng1975@126.com

X. Yi $\cdot$ G. Liu $\cdot$ M. Zhang $\cdot$ Z. Dong $\cdot$ Y. Yang College of Agriculture, Henan University of Science and

Technology, Luoyang 471003, China
$Q$. variabilis and $P$. koraiensis were higher than those of normal plants. As expected, ${ }^{15} \mathrm{~N}$ isotope was significantly diluted in the growing seedlings germinated from ${ }^{15} \mathrm{~N}$-enriched seeds. Using the ${ }^{15} \mathrm{~N}$-urea soaking method, we successfully located five seedlings of $Q$. variabilis germinated from the enriched acorns in the field.

- Discussion The ${ }^{15} \mathrm{~N}$-urea soaking technique is powerful in tracking seed dispersal and seedling recruitment. This new method solves some of the problems inherent in traditional methods for tracking secondary seed dispersal and could further improve the study of seed dispersal ecology.

Keywords Seed dispersal $\cdot$ Seed tagging $\cdot{ }^{15} \mathrm{~N}$-urea soaking . Isotope enrichment $\cdot$ Seedling establishment

\section{Introduction}

Seed dispersal by animals has significant influences on community ecology, genetic structures, and population dynamics (Jordano and Godoy 2002; Levine and Murrell 2003; Carlo et al. 2007; García et al. 2007; Moore et al. 2007; Yi et al. 2011). However, ecological assessment of seed dispersal has largely been neglected because tracing seed movements from the seed source to the exact locations where the seeds germinate or perish is difficult (Chambers and MacMahon 1994; Wang and Smith 2002; Bullock et al. 2006; Muñoz and Bonal 2011; Hirsch et al. 2012a, 2012b; Davis et al. 2011) and often suffers methodological limitations (Nathan 2006; Galvez et al. 2009; Galetti et al. 2010). Previous studies indicate that the biggest obstacle to track seed dispersal by animals is to develop a method that is simple, effective, labor-saving, and broadly applicable (Takahashi et al. 2006; García et al. 2007; Yi et al. 2008; Carlo et al. 2009; Lemke et al. 2009; Perea et al. 
2011; Hirsch et al. 2012a, 2012b). If a simple and reliable seedtracking method could be developed, it would facilitate a better understanding of seed dispersal ecology (Will and Tackenberg 2008; Yi et al. 2008; Carlo et al. 2009). Many methods have been used to track seed dispersal by animals and the resulting seed fates, e.g., direct observation (Burnell and Tomback 1985), surgical installation of metal or magnets (Alverson and Díaz 1989; Den Ouden et al. 2005), attachment of colored threads or tags to seeds (Forget 1992; Yi and Zhang 2008; Yi et al. 2011), marking with stable or radioactive isotopes (Winn 1989; Carlo et al. 2009), application of florescent microspheres and dye powders (Longland and Clements 1995; Levey and Sargent 2000; Tewksbury et al. 2002; Lemke et al. 2009), genetic techniques based on microsatellites (Godoy and Jordano 2001; García et al. 2007; Smouse et al. 2012), radio transmitters (Hirsch et al. 2012a, 2012b), as well as pit tags (Suselbeek et al. 2013). Although these methods show their own advantages and have been used in many ecosystems for tracking seed dispersal, most of them suffered from deficiencies and limitations (Alverson and Díaz 1989; Forget 1992; Levey and Sargent 2000; Godoy and Jordano 2001; Tewksbury et al. 2002; Yi et al. 2008; Niu et al. 2011; Hirsch et al. 2012a, 2012b). Carlo et al. (2009) recently introduced a new method to track seed dispersal and seed recruitment based on labeling seeds or fruits by foliar-spraying with a solution of ${ }^{15} \mathrm{~N}$-urea during the flowering stage of small herbaceous plants (Solanum americanum and Capsicum annuum). Although this method is effective and provides ability to find the exact locations that seeds arrive, germinate, and establish in the field, it is not broadly applicable for tree species with large canopies and high trunks because it is very difficult to foliar spray ${ }^{15} \mathrm{~N}$ isotope urea solutions to the canopies more than $10 \mathrm{~m}$ in height. In addition, foliar sprays applied to wind-pollinated flowers at the time of anthesis could hamper pollination and the subsequent development of seeds and fruits. Our goal in this study was to further develop the ${ }^{15} \mathrm{~N}$ stable isotope technique to track seed dispersal of tree species that are tall and have large canopies, e.g., pines and oaks. This method involved direct soaking seeds and acorns into ${ }^{15} \mathrm{~N}$ isotope urea solutions with different dosages for several days. The cotyledons or endosperm of the seeds were expected to absorb the urea so that the seeds were ${ }^{15} \mathrm{~N}$ enriched, which enables the tracking of seed dispersal and seedling recruitment in the field.

We designed our experiments to address the following five questions: (1) Can any kind of seeds be isotopically enriched in $\delta^{15} \mathrm{~N}$ values through urea solution soaking?; (2) What is the optimal dosage of ${ }^{15} \mathrm{~N}$-urea and soaking duration for seed isotope enrichment?; (3) Do enriched seeds reliably produce seedlings with $\delta^{15} \mathrm{~N}$ values higher than those of normal seedlings?; (4) What is the optimal stage to sample seedlings for ${ }^{15} \mathrm{~N}$ isotope enrichment analysis?; and (5) Is it possible to accurately discriminate seedlings produced by ${ }^{15} \mathrm{~N}$-enriched seeds against those germinated from natural seeds in the field?

\section{Materials and method}

\section{$2.1{ }^{15} \mathrm{~N}$ isotope enrichment in seeds and seedlings}

In autumn of 2011, we soaked seeds of Pinus koraiensis (Pinaceae) and acorns of Quercus variabilis (Fagaceae) and Cyclobalanopsis glauca (Fagaceae) in ${ }^{15} \mathrm{~N}$-urea solutions in Henan University of Science and Technology, Luoyang, China, to see if they and their seedlings were successfully enriched with the ${ }^{15} \mathrm{~N}$ isotope. Three dosage treatment solutions $(0,1$, and $2 \mathrm{mmol} / \mathrm{L}$ ) of ${ }^{15} \mathrm{~N}$-urea (98 atom\%; Isotec, Sigma-Aldrich, St. Louis, Missouri, USA) were used. Sound and healthylooking seeds of the three tree species were used. Trees of $Q$. variabilis and C. glauca produce large acorns rich in starch, whereas seeds of $P$. koraiensis are small and rich in fat. $P$. koraiensis was included to test whether seeds rich in fat can successfully absorb the ${ }^{15} \mathrm{~N}$-urea solution. Acorns of $Q$. variabilis exhibit no dormancy and germinate immediately at or even before seed fall (Yi et al. 2012a). In contrast, acorns of $C$. glauca and seeds of $P$. koraiensis remain dormant through winter until the next spring. This design further allows us to test whether differences in seed dormancy affects urea solution absorption. We selected 100 seeds and acorns of each tree species and separately soaked them into each dosage solution of ${ }^{15} \mathrm{~N}$-urea. Thus, 300 propagules of each tree species were used for the urea soaking experiments. Seeds and acorns with pericarps attached were half submerged in the solutions, and the solutions were stirred everyday to ensure normal respiration and metabolism of seeds/acorns. After 10 days of soaking, 15 seeds or acorns (seed coat and pericarps were excluded) of each species in each dosage solution were collected and divided into three individual samples. Each sample contained $1-3 \mathrm{~g}$ dry mass of five acorns or seeds and were ground for measurement of ${ }^{15} \mathrm{~N}$ enrichment. At the same time, 20 acorns of $Q$. variabilis in each dosage solution were randomly selected and planted into an organic soil in plastic trays with 50 grids (length $\times$ width $\times$ height: $4 \mathrm{~cm} \times 4 \mathrm{~cm} \times 6 \mathrm{~cm}$ ) to see if seedlings were enriched with ${ }^{15} \mathrm{~N}$. To determine how long the isotopic signal lasted in the growing seedlings, the aboveground parts of three seedlings were individually harvested for ${ }^{15} \mathrm{~N}$ isotope analysis when the seedlings reached 5-6 cm (first stage), 8$10 \mathrm{~cm}$ (second stage), and $12-15 \mathrm{~cm}$ (third stage) in height (see below), respectively. We then repeated the above procedures after 20 and 30 days of soaking to determine ${ }^{15} \mathrm{~N}$ enrichment both in the acorns and seedlings, respectively. To investigate if the ${ }^{15} \mathrm{~N}$-urea soaked seeds of $P$. koraiensis can reliably produce seedlings with enriched $\delta^{15} \mathrm{~N}$ values, we planted 15 seeds soaked in 0,1 , and $2 \mathrm{mmol} / \mathrm{L}{ }^{15} \mathrm{~N}$-urea for 20 days in the plastic trays, respectively (this procedure allows us to save money for isotope analysis). When the seedlings reached the maximum of the first flush (see below), the aboveground parts of three seedlings at each dosage solution were individually harvested for ${ }^{15} \mathrm{~N}$ isotope analyses. 


\subsection{Assessing seedling recruitment in the field}

To investigate whether the ${ }^{15} \mathrm{~N}$ soaking method is suitable for seed dispersal and seedling assessing, we conducted a field experiment using ${ }^{15} \mathrm{~N}$-enriched acorns of $Q$. variabilis soaked in $2 \mathrm{mmol} / \mathrm{L}{ }^{15} \mathrm{~N}$-urea solution for 20 days. In December 2011, $600{ }^{15} \mathrm{~N}$-enriched acorns were selected and released at two seed stations $\left(2 \times 2 \mathrm{~m}^{2}\right)$ in Tianchi Mountain Natural Reserve, Luoyang, China (average elevation $\left.1,400 \mathrm{~m}, 33^{\circ} 45^{\prime}-33^{\circ} 85^{\prime} \mathrm{N}, 111^{\circ} 75^{\prime}-112^{\circ} 45^{\prime} \mathrm{E}\right)$, with 300 acorns in each station. Seed removal rate and seed fate were not checked. Previous studies in the experimental area show that small rodents (Sciurotamis davidianus, Apodemus peninsulae, Niviventer confucianus, Apodemus agrarius, and Tscherskia triton) usually disperse acorns less than $25 \mathrm{~m}$ (Yi's unpublished data); therefore, one-year seedlings (6-10 cm high) of $Q$. variabilis were located around each seed station (radius $\approx 30 \mathrm{~m}$ ) and were sampled for ${ }^{15} \mathrm{~N}$ isotope analysis in the spring of 2012. The epicotyl was sampled from each seedling and was cleaned and dried for ${ }^{15} \mathrm{~N}$ isotope analysis. The enriched seedlings were identified by comparing with the natural ${ }^{15} \mathrm{~N}$ values in nature (Craine et al. 2012).

\subsection{Stable isotope analysis}

All samples (seeds, acorns, and seedlings) were cleaned using distilled water and air-dried to constant weight in an oven at $70{ }^{\circ} \mathrm{C}$ for $48 \mathrm{~h}$. They were ground finely and placed in an isotope ratio spectrometer for isotopic analysis using elemental analyzer/continuous flow isotope ratio mass spectrometry. Samples were analyzed for stable nitrogen isotope abundance at the Laboratory of Stable Isotope Spectrometer, Chinese Academy of Forestry Sciences (Beijing). Interface between element-analysis meter and spectrometer was Flash EA1112 HT (Thermo Finnigan, USA). Operation condition: oxidizing furnace temperature was $900^{\circ} \mathrm{C}$, reducing furnace was $680^{\circ} \mathrm{C}$, and pillar temperature was $40{ }^{\circ} \mathrm{C}$. The resulting $\mathrm{N}_{2}$ was purified in a vacuum line and injected in a Finnigan MAT Delta $\mathrm{V}$ advantage spectrometer (Thermo Fisher Scientific, Inc., USA) fitted with double inlet and collector systems. The results are expressed in $\delta^{15} \mathrm{~N}$ relative to the standards in the conventional $\delta$ per mil notation with a standard deviation of 0.2 per mil:

$\delta^{15} \mathrm{~N}=\left[\left({ }^{15} \mathrm{~N} /{ }^{14} \mathrm{~N}\right)\right.$ sample $/\left({ }^{15} \mathrm{~N} /{ }^{14} \mathrm{~N}\right)$ standard -1$] \times 1000$

Where ${ }^{15} \mathrm{~N} /{ }^{14} \mathrm{~N}$ are the isotopic ratios of sample and standard (atmospheric nitrogen).

\subsection{Data analysis}

We conducted all statistical analyses in SPSS 16.0. Two-way ANOVA was used to test the effects of soaking duration and urea dosage on ${ }^{15} \mathrm{~N}$ enrichment in the seeds or acorns of $Q$. variabilis, $C$. glauca, and $P$. koraiensis. Three-way ANOVA was applied to detect the effects of soaking duration, urea dosage, and sampling stage on ${ }^{15} \mathrm{~N}$ enrichment in the seedlings of $Q$. variabilis. Because the effects of soaking duration and sampling stage were not evaluated, difference in the ${ }^{15} \mathrm{~N}$ enrichment in seedlings of $P$. koraiensis in response to urea dosage was tested using one-way ANOVA. A nonparametric MannWhitney test was used to compare the difference in ${ }^{15} \mathrm{~N}$ enrichment in the seedlings of $Q$. variabilis collected from the field.

\section{Results}

$3.1{ }^{15} \mathrm{~N}$ enrichment in acorns/seeds

Our soaking experiments showed that the dosage of ${ }^{15} \mathrm{~N}$-urea solution had significant effects on ${ }^{15} \mathrm{~N}$ enrichment in the acorns of $Q$. variabilis $(F=17.680, \mathrm{df}=2, P<0.001)$ (Fig. 1). The dosage of $2 \mathrm{mmol} / \mathrm{L}{ }^{15} \mathrm{~N}$-urea solution resulted in much higher ${ }^{15} \mathrm{~N}$ in acorns than those of 0 and $1 \mathrm{mmol} / \mathrm{L}$ solutions (all $P<0.001$ ). However, we found no significant influence of soaking duration on ${ }^{15} \mathrm{~N}$ enrichment in the acorns $(F=2.520, \mathrm{df}=2, P=0.108)$ (Fig. 1). Similarly, we detected significant effects of urea dosage on ${ }^{15} \mathrm{~N}$ enrichment in the acorns of $C$. glauca and seeds of $P$. koraiensis $(F=23.338$, $\mathrm{df}=2, P<0.001 ; F=3.366, \mathrm{df}=2, P=0.057$ ) (Fig. 2). Soaking duration showed no effect on ${ }^{15} \mathrm{~N}$ enrichment in seeds or acorns of these two tree species $(F=1.064, \mathrm{df}=2, P=0.366$; $F=1.928, \mathrm{df}=2, P=0.174)$ (Fig. 2$)$.

\section{$3.2{ }^{15} \mathrm{~N}$ enrichment in seedlings}

Three-way ANOVA indicated significant effects of soaking duration, urea dosage, and sampling stage on ${ }^{15} \mathrm{~N}$ enrichment in the seedlings of $Q$. variabilis $(F=9.159, \mathrm{df}=2, P<0.001$; $F=31.884, \mathrm{df}=2, P<0.001 ; F=4.713, \mathrm{df}=2, P=0.013)$ (Fig. 3). We also found a significant interaction effect between any two of the three factors (all $P<0.05$ ). Multiple

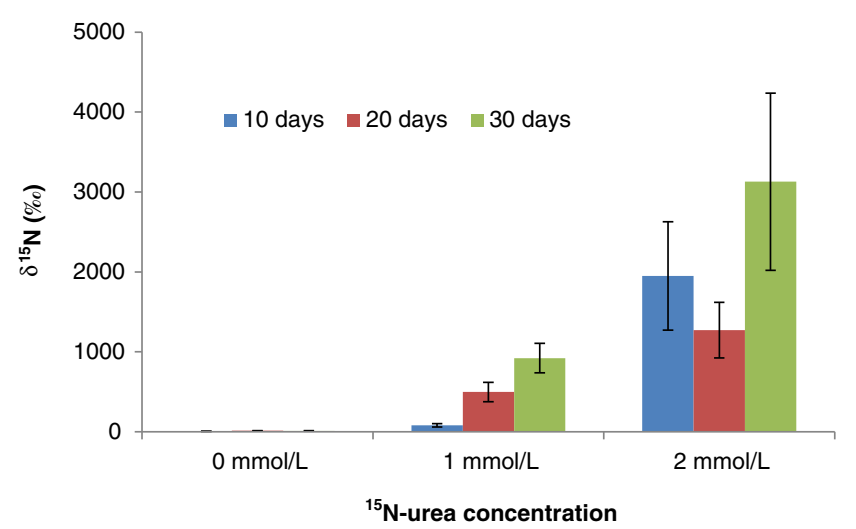

Fig. 1 The effects of urea dosage and soaking duration on ${ }^{15} \mathrm{~N}$ enrichment in the acorns of $Q$. variabilis. Data are expressed as mean $\pm \mathrm{SE}$ 
Fig. 2 The effects of urea dosage and soaking duration on ${ }^{15} \mathrm{~N}$ enrichment in the propagules of C. glauca and P. koraiensis. Data are expressed as mean $\pm \mathrm{SE}$

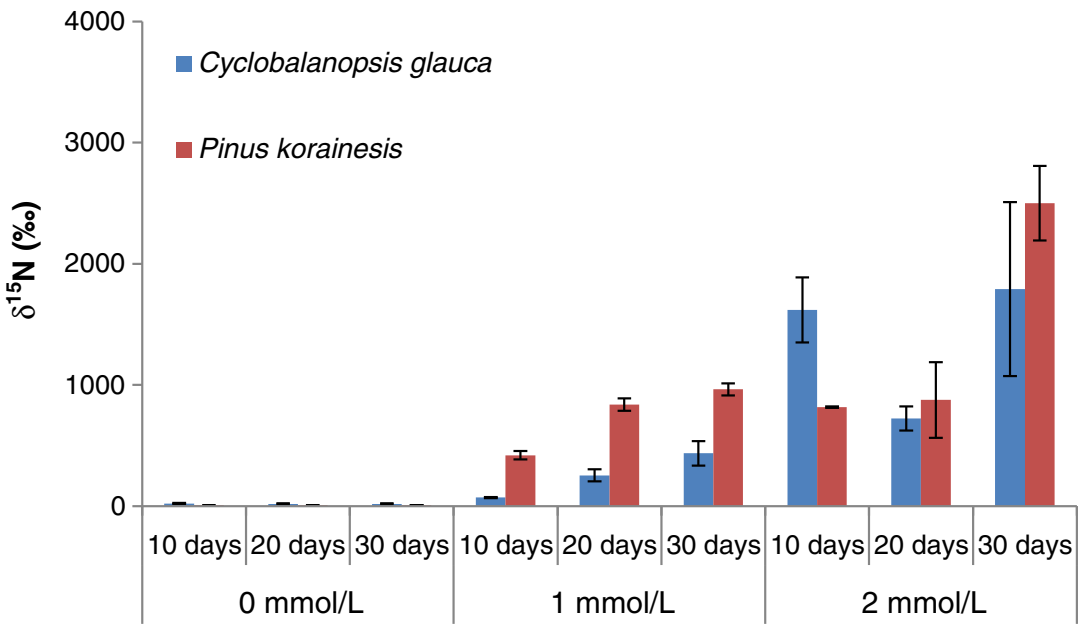

comparisons further demonstrated that ${ }^{15} \mathrm{~N}$ values in the seedlings sampled at the third stage $(12-15 \mathrm{~cm}$ high) were much lower than those sampled at the first and second stages ( $P=0.003 ; P=0.145$, respectively) (Fig. 3), indicating that seedlings $8-10 \mathrm{~cm}$ in height are optimal to be sampled
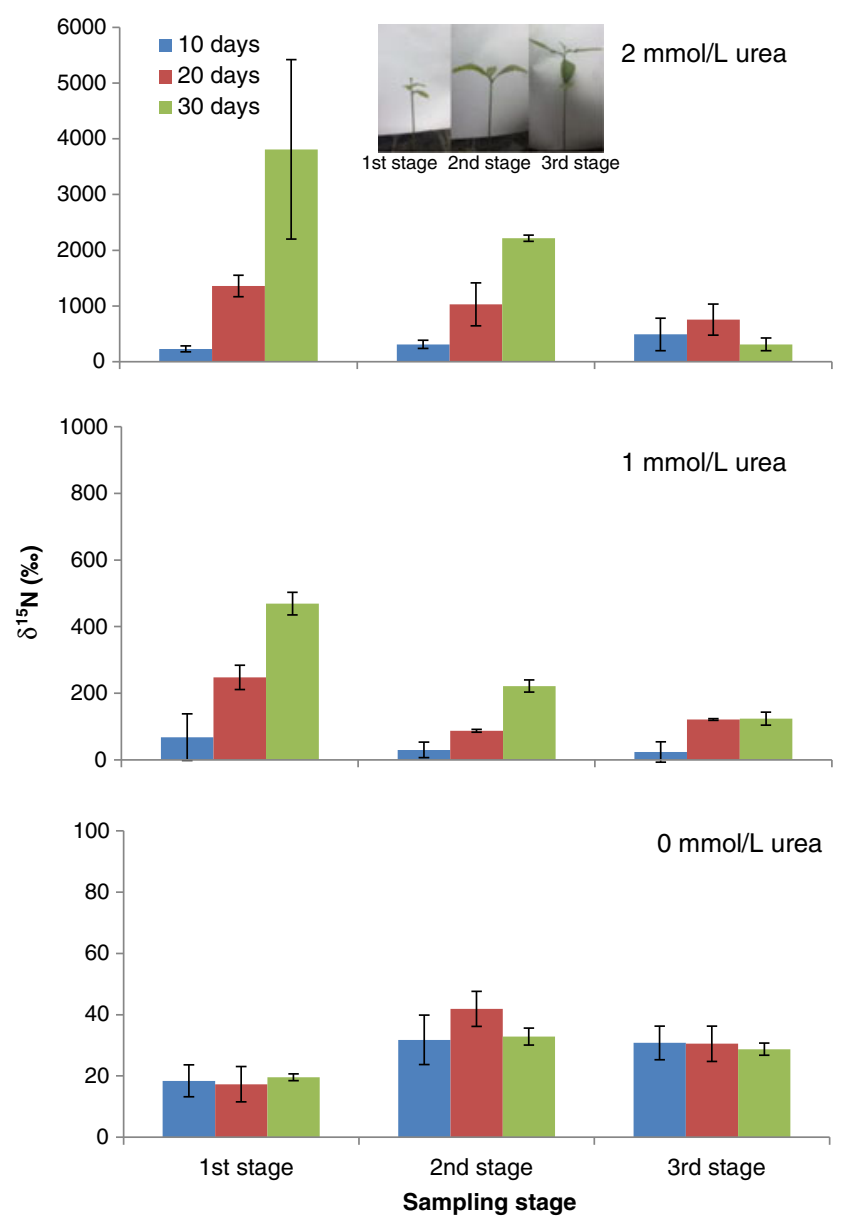

Fig. 3 The effects of urea dosage, soaking duration, and sampling stage on ${ }^{15} \mathrm{~N}$ enrichment in the seedlings of $Q$. variabilis. Embedded images indicate three seedling sampling stages. Data are expressed as mean $\pm \mathrm{SE}$ for ${ }^{15} \mathrm{~N}$ isotope analysis. Although no effect of soaking duration on isotope level in acorns was observed, seedlings produced by acorns soaked for 30 days exhibited much higher ${ }^{15} \mathrm{~N}$ values than those soaked for 10 and 20 days, respectively $(P<0.001 ; P=0.015)$ (Fig. 3). Multiple comparison tests also indicated that seedlings produced by acorns soaked in $2 \mathrm{mmol} / \mathrm{L}$ dosage solution exhibited much higher ${ }^{15} \mathrm{~N}$ values than those soaked in 0 and $1 \mathrm{mmol} / \mathrm{L}$ dosage solutions, respectively (all $P<0.001$ ). We found a reliable and gradual ${ }^{15} \mathrm{~N}$ enrichment in $P$. koraiensis seedlings produced by seeds soaked in 0,1 , and $2 \mathrm{mmol} / \mathrm{L}$ dosage urea solutions for 20 days $(F=179.837, \mathrm{df}=2, P<0.001)$ (Fig. 4).

\section{$3.3{ }^{15} \mathrm{~N}$-enriched seedlings in the field}

In the spring of 2012, we located 28 seedlings of $Q$. variabilis around the two seed stations (radius $\approx 30 \mathrm{~m}$ ) through extensive search by two people for 2 days. Stable nitrogen isotope analyses indicated that five of them showed much higher $\delta^{15} \mathrm{~N}$ values $(867.28 \pm 177.89 \%)$ than normal seedlings $(10.89 \pm$ $0.47 \%$ ) $(Z=3.449, P=0.001)$ (Fig. 5), indicating that these five unnatural seedlings definitely were originated from the enriched acorns we released in the winter of 2011. The average distance between the enriched seedlings and the corresponding seed stations was $11.9 \pm 4.0 \mathrm{~m}$. We failed to detect seedlings from the other $595{ }^{15} \mathrm{~N}$-enriched acorns possibly because they were either consumed, larder hoarded, or perished.

\section{Discussion}

4.1 Effectiveness of isotopic urea soaking method

Our experiments clearly showed that ${ }^{15} \mathrm{~N}$ isotope was successfully incorporated into the acorns and seeds of $Q$. variabilis, C. glauca, and P. koraiensis. ${ }^{15} \mathrm{~N}$ enrichment could be 


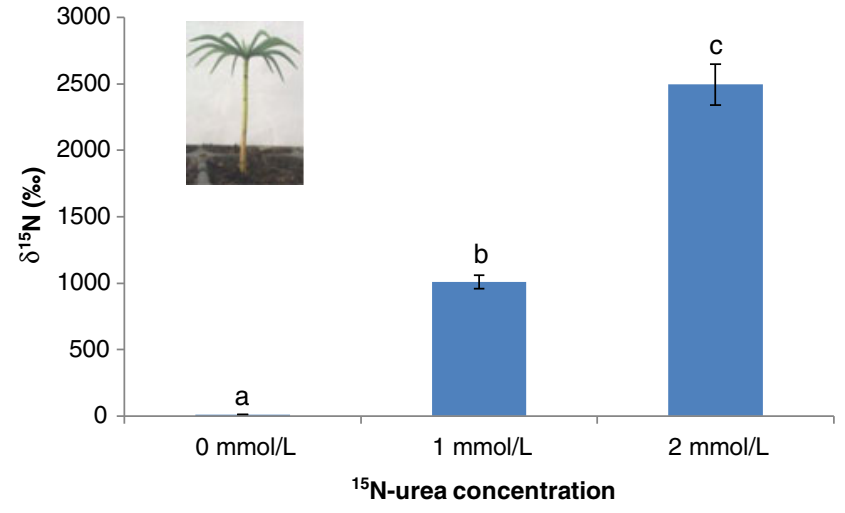

Fig. 4 The effects of ${ }^{15} \mathrm{~N}$-urea dosage on ${ }^{15} \mathrm{~N}$ enrichment in the seedlings of $P$. koraiensis. Different letters on the histograms indicate significance at $\alpha=0.05$ level. Embedded image indicates seedling sampling stage. Data are expressed as mean $\pm \mathrm{SE}$

expected in the seedlings of other tree species through urea soaking because we observed a very high enrichment of stable $\mathrm{N}$ isotope in the seedlings of $Q$. variabilis and $P$. koraiensis in the present study. We found that ${ }^{15} \mathrm{~N}$ enrichment in the seeds and seedlings were urea dosage and sampling stagedependent. While, the significant effect of soaking duration on ${ }^{15} \mathrm{~N}$ enrichment in seedlings but not in acorns can possibly be explained by the absorption of ${ }^{15} \mathrm{~N}$ from the pericarps by $Q$. variabilis seedlings because acorns were not shelled when sowing. Higher concentration of ${ }^{15} \mathrm{~N}$-urea and longer duration of soaking would generate higher levels of ${ }^{15} \mathrm{~N}$ enrichment both in seeds and seedlings. These findings address the first four questions we addressed in the introduction. According to the results of our experiments, we recommended a treatment of $2 \mathrm{mmol} / \mathrm{L}{ }^{15} \mathrm{~N}$-urea dosage and 20-day soaking duration for labeling seeds and tracking seedling recruitment in the field. However, ${ }^{15} \mathrm{~N}$ isotope tended to be diluted in the growing seedlings, echoing the results of Carlo et al. (2009). Therefore, sampling seedlings in proper development stage is crucial for ${ }^{15} \mathrm{~N}$ isotope analysis. Taking ${ }^{15} \mathrm{~N}$-urea concentration and seedling morphological performance into account, we suggest that

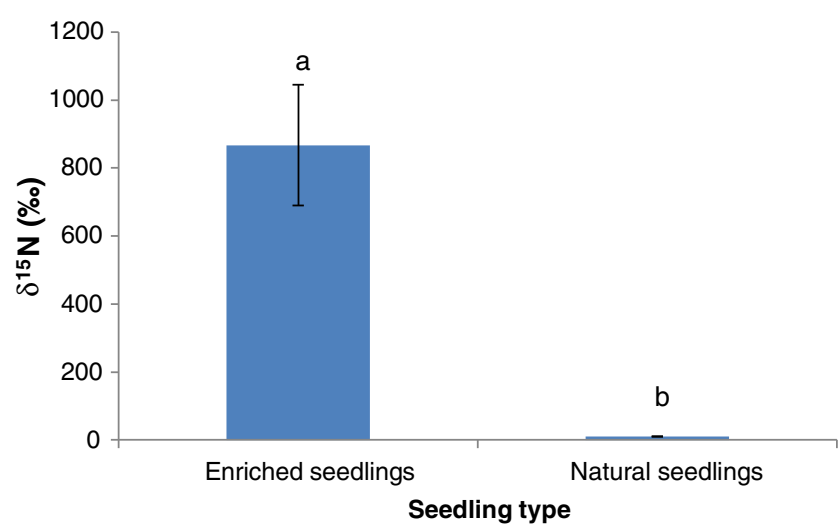

Fig. 5 Difference between $\delta^{15} \mathrm{~N}$ values of enriched seedlings and background seedlings collected in the field. Different letters on the histograms indicate significance at $\alpha=0.05$ level. Data are expressed as mean $\pm \mathrm{SE}$
$8-10 \mathrm{~cm}$ high seedlings are ideal for sampling and ${ }^{15} \mathrm{~N}$ analysis. Compared with the natural ${ }^{15} \mathrm{~N}$ values in nature (Craine et al. 2012), we successfully tracked several seedlings produced by ${ }^{15} \mathrm{~N}$-enriched acorns of $Q$. variabilis in the field, verifying the feasibility of ${ }^{15} \mathrm{~N}$-urea soaking to tag seeds for tracking their dispersal and recruitment. Compared to the urea foliar-spraying method (Carlo et al. 2009), soaking seeds directly in ${ }^{15} \mathrm{~N}$-urea circumvented some methodological problems encountered when trying to label propagules of large plants with high trunks and canopies that are difficult to reach.

\subsection{Pros and cons of the soaking method}

Our study on these three tree species suggests that isotope marking by ${ }^{15} \mathrm{~N}$-urea soaking is useful to investigate seed dispersal and seedling recruitment. Although this method omits the exact seed movement provided by animals during the dispersal process in the field, it is more labor-saving and less costly compared to molecular analyses to identify the mother trees (Godoy and Jordano 2001; Carlo et al. 2009). Therefore, our method permits the exact location of the seedling establishment to be determined, which facilitates the measurement of dispersal distance from the parent plants. This new isotope marking method overcomes the methodological bottlenecks that "large plants or trees will require large volumes of urea solutions, and canopies are obviously hard to reach" (Carlo et al. 2009). ${ }^{15} \mathrm{~N}$-urea solution soaking method also avoids the influence of weather conditions and manual application procedures on the variations in $\delta^{15} \mathrm{~N}$ values that urea foliar-spraying methods usually face. Although this method is not very suitable for tracking seed dispersal of many individuals within the same site, distinction among seeds and seedlings can be made by the dosage level provided (Carlo et al. 2009). Moreover, searching for enriched seedlings in large areas is expected to be much easier than searching for enriched seeds passed through avian passage (Carlo et al. 2009). Compared to the traditional tracking methods (Iida 1996, 2006; Yi and Zhang 2008; Yi et al. 2011; Canner and Spence 2011), the ${ }^{15} \mathrm{~N}$-urea solution soaking method provides a nondestructive approach to track seed dispersal, which will authentically reflect the seed dispersal processes because the traditional methods always involve surgical manipulations on seeds (e.g., inserting magnets or transmitters, drilling holes, and attaching transmitters) (Alverson and Díaz 1989; Winn 1989; Forget 1992; Den Ouden et al. 2005; Pons and Pausas 2007; Yi and Zhang 2008; Yi et al. 2011). These manipulations frequently lead to unexpected seed death, fungal contamination, seed weight modification, and seed consumption (Alverson and Díaz 1989; Den Ouden et al. 2005; Iida 1996, 2006; Canner and Spence 2011; Hirsch et al. 2012a, 2012b). Furthermore, our isotope tagging method shows an advantage over the traditional methods (Yi et al. 2008; Niu et al. 2011; Hirsch et al. 2012a, 2012b) that it does not add any visual cues to the ${ }^{15} \mathrm{~N}$-enriched seeds, which resembles the natural seeds and prevents animals from using 
these cues for recovering the cached seeds. This method also has several shortcomings: (1) it requires much effort to locate all potential seedlings over a wide area after seed dispersal, and therefore (2) it is not well appropriate for long distance dispersal by fruigivory, (3) although it may be powerful to study "secondary dispersal" such as scatterhoarding by rodents and similar processes, the urea soaking method does not permits the study of dispersal of plants that obtain seed removal directly from the canopies (like fruigivory). Therefore, ${ }^{15} \mathrm{~N}$-urea soaking approach is expected to have a great potential for providing insights into seed dispersal and seedling recruitment manipulated by scatterhoarding animals.

\subsection{Broad application of tracking seed dispersal}

Although seeds of the three tree species are different in the germination schedule (dormant or nondormant), chemical composition (e.g., tannin), seed coat thickness, and morphological size, ${ }^{15} \mathrm{~N}$ isotope was ubiquitously enriched in seeds and seedlings of $Q$. variabilis, C. glauca, and $P$. koraiensis. These facts imply that ${ }^{15} \mathrm{~N}$ enrichment is unlikely to be affected by seed trait. Traditional seed-tracking methods are often limited by the size of seeds, and thus, only seeds of large size are selected for labeling and tracking (Sone and Kohno 1996; Mack and Druliner 2003; Yi et al. 2008, 2012b). Given that seed species of any size can successfully germinate and establish, our method makes it possible to track dispersal and recruitment of both small- and largeseeded plant species. Although our method may not efficient to study "natural" removal rates of seeds, especially those seeds contained within fleshy fruits, it is expected to be ideal for "seed addition" experiments to track seed dispersal of some tree species (Nathan and Mueller-Landau 2000; Clark et al. 2007). Our study verified the validation of ${ }^{15} \mathrm{~N}$-urea soaking in tracking seed dispersal and seedling recruitment of a number of tree species and provided the confidence to distinguish between the seeds added and those arrived naturally. We believe that this promising method will improve the seed-tracking efficiency of seed dispersal ecology.

Acknowledgments We thank Tianchi Mountain Natural Reserve, Luoyang, Henan for allowing us to carry out the field experiments.

Funding This study was funded by the Natural Science Foundation of China (nos. 31172101 and 41203018) and the Program for New Century Excellent Talents in University (NCET-12-0693).

\section{References}

Alverson WS, Díaz AG (1989) Measurement of the dispersal of large seeds and fruits with a magnetic locator. Biotropica 21:61-63

Bullock JM, Shea K, Skarpaas O (2006) Measuring plant dispersal: an introduction to field methods and experimental design. Plant Ecol 186:217-234
Burnell KL, Tomback DF (1985) Steller's jays steal gray jay caches: field and laboratory observations. Auk 102:417-419

Canner JE, Spence M (2011) A new technique using metal tags to track small seeds over short distances. Ecol Res 26:233236

Carlo TA, Aukema JE, Morales JM (2007) Plant-frugivore interactions as spatially explicit networks: integrating animal foraging and fruiting plant spatial patterns. In: Dennis A, Schupp E, Westcott D (eds) Seed dispersal: theory and its application in a changing world. CABI, Oxon, pp 369-390

Carlo TA, Tewksbury J, del Rio CM (2009) A new method to track seed dispersal and recruitment using ${ }^{15} \mathrm{~N}$ isotope enrichment. Ecology 90 : 3516-3525

Chambers JC, MacMahon JA (1994) A day in the life of a seed: movements and fates of seeds and their implications for natural and managed systems. Ann Rev Ecol Syst 25:263-292

Clark CJ, Poulsen JR, Levey DJ, Osenberg CW (2007) Are plant populations seed limited? A critique and meta-analysis of seed addition experiments. Am Nat 170:28-142

Craine JM, Wolkovich EM, Towne EG, Kembel SW (2012) Flowering phenology as a functional trait in a tallgrass prairie. New Phytol 193: 673-682

Davis AS, Daedlow D, Schutte BJ, Westerman PR (2011) Temporal scaling of episodic point estimates of seed predation to long-term predation rates. Methods Ecol Evol 2:682-890

Den Ouden J, Jansen PA, Smit R (2005) Jays, mice and oaks: predation and dispersal of Quercus robur and Q. petraea in north-western Europe. In: Forget PM, Lambert JE, Hulme PE, Vander Wall SB (eds) Seed fate: predation, dispersal and seedling establishment. CABI, Wallingford, pp 223-240

Forget PM (1992) Seed removal and seed fate in Gustavia superba (Lecythidaceae). Biotropica 24:408-414

Galetti M, Donatti CI, Steffler C, Genini J, Bovendorp RS, Fleury M (2010) The role of seed mass on the caching decision by agoutis, Dasyprocta leporina (Rodentia: Agoutidae). Zoologia 27:472-476

Galvez D, Kranstauber B, Kays RW, Jansen PA (2009) Scatter hoarding by the Central American agouti: a test of optimal cache spacing theory. Anim Behav 78:1327-1333

García C, Jordano P, Godoy JA (2007) Contemporary pollen and seed dispersal in a Prunus mahaleb population: patterns in distance and direction. Mol Ecol 16:1947-1955

Godoy JA, Jordano P (2001) Seed dispersal by animals: exact identification of source trees with endocarp DNA microsatellites. Mol Ecol 10:2275-2283

Hirsch BT, Kays R, Jansen PA (2012a) A telemetric thread tag for tracking seed dispersal by scatter-hoarding rodents. Plant Ecol 213:933-943

Hirsch BT, Visser MD, Kays R, Jansen PA (2012b) Quantifying seed dispersal kernels from truncated seed-tracking data. Methods Ecol Evol 3:595-602

Iida S (1996) Quantitative analysis of acorn transportation by rodents using magnetic locator. Vegetatio 124:39-43

Iida S (2006) Dispersal of Quercus serrata acorns by wood mice in and around canopy gaps in a temperate forest. Forest Ecol Manage 227: $71-78$

Jordano P, Godoy JA (2002) Frugivore-generated seed shadows: a landscape view of demographic and genetic effects. In: Levey D, Silva WR, Galetti M (eds) Seed dispersal, fruigivory: ecology, evolution, conservation. CABI, Wallingford, pp 305-321

Lemke A, von der Lippe M, Kowarik I (2009) New opportunities for an old method: using fluorescent colours to measure seed dispersal. J Appl Ecol 46:1122-1128

Levey DJ, Sargent S (2000) A simple method for tracking vertebratedispersed seed. Ecology 81:267-274

Levine JM, Murrell DJ (2003) The community-level consequences of seed dispersal patterns. Ann Rev Ecol Syst 34:549-574 
Longland WS, Clements C (1995) Use of fluorescent pigments in studies of seed caching by rodents. J Mammal 76:1260-1266

Mack AL, Druliner G (2003) A non-intrusive method for measuring movements and seed dispersal in cassowaries. J Field Ornithol 74:193-196

Moore J, McEuen AB, Swihart RK, Contreras TA, Steele MA (2007) Determinants of seed removal distance by scatter-hoarding rodents in deciduous forests. Ecology 88:2529-2540

Muñoz A, Bonal R (2011) Linking seed dispersal to cache protection strategies. J Ecol 99:1016-1025

Nathan R (2006) Long-distance dispersal of plants. Science 313:786-788

Nathan R, Mueller-Landau HC (2000) Spatial patterns of seed dispersal, their determinants and consequences for recruitment. Trends Ecol Evol 15:278-285

Niu KK, Jiao GQ, Yu F, Yi XF (2011) Study on seed finding by Tamius sibiricus in semi-natural enclosures. Chin J Zool 46:45-51, in Chinese with English abstract

Perea R, San Miguel A, Gil L (2011) Leftovers in seed dispersal: ecological implications of partial seed consumption for oak regeneration. J Ecol 99:194-201

Pons J, Pausas JG (2007) Acorn dispersal estimated by radio tracking. Oecologia 153:903-911

Smouse PE, Sork VL, Scofield DG, Grivet D (2012) Using seedling and pericarp tissues to determine maternal parentage of dispersed valley oak recruits. J Hered 103:250-259

Sone K, Kohno A (1996) Application of radiotelemetry to the survey of acorn dispersal by Apodemus mice. Ecol Res 11:187-192

Suselbeek L, Jansen PA, Prins HHT, Steele MA (2013) Tracking rodentdispersed large seeds with Passive Integrated Transponder (PIT) tags. Methods in Ecol Evol. doi:10.1111/2041-210X.12027
Takahashi K, Sato K, Washitani I (2006) The role of the wood mouse in Quercus serrata acorn dispersal in abandoned cut-over land. Forest Ecol Manage 229:120-127

Tewksbury JJ, Levey DJ, Haddad NM, Sargent S, Orrock JL, Weldon A, Danielson BJ, Brinkerhoff J, Damschen EI, Townsend P (2002) Corridors affect plants, animals, and their interactions in fragmented landscapes. Proceed Nat Acad Sci 99:12923-12926

Wang BC, Smith TB (2002) Closing the seed dispersal loop. Trends Ecol Evol 17:379-385

Will H, Tackenberg O (2008) A mechanistic simulation model of seed dispersal by animals. J Ecol 96:1011-1022

Winn AA (1989) Using radionuclide labels to determine the postdispersal fate of seeds. Trends Ecol Evol 4:1-2

Yi XF, Zhang ZB (2008) Seed predation and dispersal of glabrous filbert (Corylus heterophylla) and pilose filbert (Corylus mandshurica) by small mammals in a temperate forest, northeast China. Plant Ecol 196:135-142

Yi XF, Xiao ZS, Zhang ZB (2008) Seed dispersal of Korean pine Pinus koraiensis labeled by two different tags in a northern temperate forest, northeast China. Ecol Res 23:379-384

Yi XF, Yang YQ, Zhang ZB (2011) Different interspecific effects of mast seeding on seed removal of two sympatric Corylus species. Plant Ecol 212:785-793

Yi XF, Yang YQ, Curtis R, Bartlow AW, Agosta SJ, Steele MA (2012a) Alternative strategies of seed predator escape by early-germinating oaks in Asia and North America. Ecol Evol 2:487-492

Yi XF, Steele MA, Zhang ZB (2012b) Acorn pericarp removal as a cache management strategy of the Siberian chipmunk. Ethology 118:87-94 